\title{
Urban Growth During Civilian and Military Administrations in Osogbo, Nigeria
}

\section{Olalekan John TAIWO}

Received: Sept 2016 / Accepted: June 2018

(92018 Faculty of Geography UGM and The Indonesian Geographers Association

\begin{abstract}
Research on comparative analysis of urban growth and structure during military and civilian regimes most especially in Africa where coup detats is common and where land is mainly controlled by private individuals is limited. This study analysed the temporal patterns and morphological characteristics of urban growth during the military and civilian regimes as well as during different civilian administrations using eight landscape metrics. Landsat satellite images of 1984, 1991, 2000, 2003, 2010 and 2014 were used in the analysis. It was found that urban growth occurred primarily through expansion (annexation) of extant urban areas rather than spontaneous and detached development.
\end{abstract}

Keywords: Urban growth, military administration, civilian administration, annexation, urban nuclei formation

Abstrak Penelitian tentang analisis komparatif tentang pertumbuhan dan struktur perkotaan selama rezim militer dan sipil terutama di Afrika di mana kudeta berlaku umum dan di mana lahan terutama dikendalikan oleh perorangan terbatas. Studi ini menganalisis pola temporal dan karakteristik morfologi pertumbuhan perkotaan selama rezim militer dan sipil serta selama pemerintahan sipil yang berbeda menggunakan delapan metrik lanskap. Citra satelit Landsat tahun 1984, 1991, 2000, 2003, 2010 dan 2014 digunakan dalam analisis. Ditemukan bahwa pertumbuhan perkotaan terjadi terutama melalui ekspansi (aneksasi) daerah perkotaan yang masih ada daripada pembangunan spontan dan terpisah.

Kata kunci: Pertumbuhan perkotaan, administrasi militer, administrasi sipil, aneksasi, pembentukan nukleus perkotaan

\section{Introduction}

Politics is the moral and material context through which production, distribution, and consumption are organised in space [Polanyi, 1944; Molotch, 1993]. Favourable political and contextual environment are among the necessary preconditions not only for the production of urban space but also urban growth. Government can initiate urban expansion through the provision of site and service at peri-urban locations or create investment incentives that result in land use conversion. The growth boundary approach can however be used to control urban encroachment into farm and forest lands (urban sprawl), while at the same time promoting the efficient use of land, public facilities and services within the boundary. Arguably, many times, urban growth and the associated land use conversion patterns respond and are controlled by state power, most especially in democratic systems [SoleOlle, and Viladecans-Marsal, 2013]. In contemporary democracies, politics and political ideologies of the ruling parties, thus exert considerable influence on the pattern and direction of urban growth. Solé-Ollé and Viladecans-Marsal [2013] noted that cities controlled by left-wing parties convert much less land to urban uses than those controlled by the right wing. Divergent urban growth outcomes may, however, be explained in

Olalekan John TAIWO

Department of Geography, Faculty of the Social Sciences University of Ibadan

Corespondent Email: olalekantaiwo@gmail.com terms of the political resources and incentives available to the governing elite [Goodfellow, 2013]. Although, the identification of the effects of a particular political party on land use policies may not be straight forward because of the complexity of actors and stakeholders involved [Logan and Molotch, 1987].

Democracy in African may be regarded as nascent because of the several military coup détats witnessed in the continent. Most countries in the West African Sub region have experienced at least one coups détat since independence. Military rulers often accused civilian government of corruption, incompetence and the mismanagement of the national economy. The highest number of military coups d'états in the West African sub-region were in Burkina Faso (9) and Nigeria (8). Military rule in these countries lasted in some cases for many years before handling over to democratically elected politicians. Indeed, democracy can either facilitate development or hinders it or better still bears no independent relationship with it [Sirowy and Inkeles, 1990]. Researchers have argued that democracy and democratic institutions enhances growth and development, while others noted that military are not better than civilians in running governments most especially based on experience from Africa [Wangome, 1985]. The long years of military incursion into politics in Africa therefore make it imperative not only to compare the production of urban space during military and democratic regimes but also the emerging city structures during the two regimes. Differences in land 
use conversion intensity under the civilian and military administrations could result from uncertainties that usually characterise political climate during military administrations, which may ultimately reduce the intensity of land conversion.

Analysis of the pattern and trend in urban growth has benefited from advancements in remote sensing and image processing [Xiao et al., 2006]. Historical change in built-up area can be analysed using time series images [Seto et al., 2007; Yu and Ng, 2007; Zang et al., 2014]. Band ratio, image thresholding and image differencing are among the techniques used in investigating urban area dynamics from satellite images [Schneider, 2012]. Urban area delineation from satellite images have been greatly improved in the recent times with the availability of high resolution satellite image. The improvement has also brought about changes in the techniques of built-up areas delineation. Apart from the analysis of the physical growth of urban areas, landscape metrics previously used in ecological studies have also been used to understand the structural and morphological dynamics in urban areas [Seto et al., 2007; Zang et al., 2014].

The scale dependent nature of most of the identified factors of urban growth provided the basis for the continuous research on urban growth dynamics [Shu et al., 2014]. Accessibility, land control policies, physical conditions, economic opportunities, land market, population growth, gross domestic product (GDP), foreign direct investment (FDI), and improved transportation are among key drivers of urban growth in most developing countries [Thapa and Murayama, 2010; Zhang et al., 2013; Shu et al., 2014]. Limited research however exists on the effect of different political administration on urban growth especially in Africa which has experienced a mixture of military and civilian administrations. Available literatures in this regard have mainly focused on the

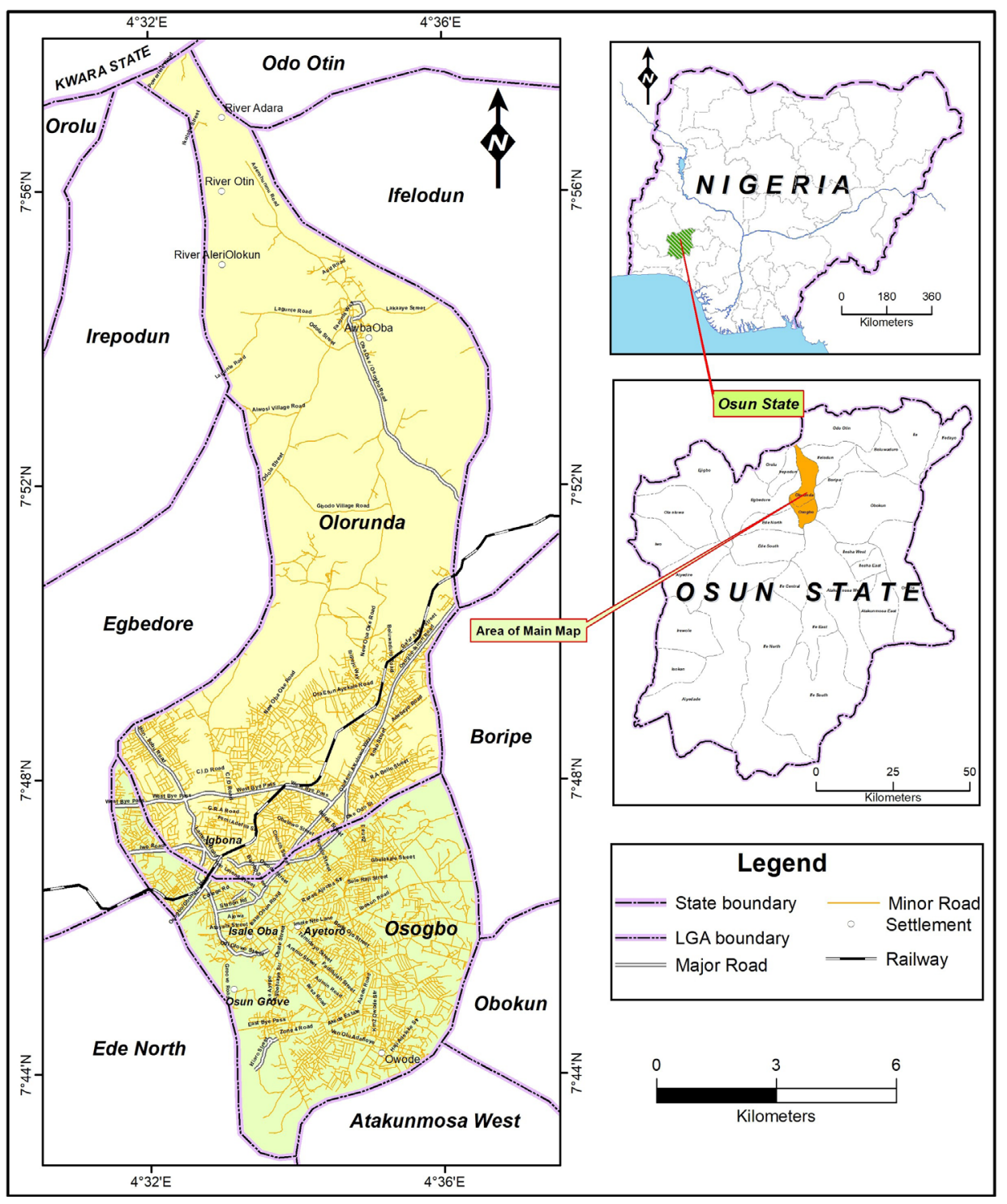

Figure 1. Olorunda and Osogbo Local Government Areas which Constitute the Study Area 
impacts of different political administration on rural land use and land cover change [Kanianska et al., 2014] and also on the relative importance of different government administrative hierarchy (the three major interest groups in a local land market, namely: the central government, the local government, and local developers) on urban growth [Zhang et al., 2014]. However, attempts have not been made to assess urban growth under different political administrations, most especially in Africa where there have been several coups d'etats and where land is predominantly controlled by private individuals [Sole-Olle, and Viladecans-Marsal, 2013]. This study, therefore, analysed the amount of land converted into urban uses (urban growth) and the structure of such conversion during the military and civilian administrations. The objective is to conduct a comparative analysis of the temporal pattern and structural characteristics of urban expansions during the military and civilian administrations and also among different political parties in Osun State.

\section{The Methods}

The analysis of the temporal trend in urban growth in Osogbo was conducted using Landsat Thematic Mappers (TM) and Landsat Enhanced Thematic Mappers (ETM+) imageries. The image selection coincided with either the end of or the beginning of each administration (Table 1). Clear cloud free Landsat images of 1984, 1991, 2003, 2010, and 2014 were downloaded from the website of the National Agency for Space Administration (NASA). The study area is the Osogbo metropolis which comprises of two local government areas (LGAs), namely Osogbo and Olorunda (Figure 1). All the satellite images were clipped to the boundary of these two LGAs. Using the image bands 4,3,2 made it possible to differentiate builtup areas from non-built-up areas because urban areas appeared bluish-grey to steel-grey [Gupta and Prakash, 1998; Huang et al., 2007]. The 2010 Landsat ETM+ was corrected for the Scanned Line Correction (SLC) error by using image-enhancement techniques, followed by nearest-neighbour interpolation [Ramachandra et al., 2012]. Maximum Likelihood classification approach was used in separating the images into three distinct land use and cover types based on a 95\% likelihood for each land use type. A majority filter analysis was used to dissolve spurious pixels within large classes. Built-up area was subsequently extracted from other land use/ cover types and its area computed. Urban areas refer to the built-up areas as indicated in the satellite images [Huang et al., 2007].

The urban growth pattern during each political regime was examined using eight different spatial metrics [Huang et al., 2007]. Since no single metric can fully captures the complexity of the spatial arrangement of patches; a set of indices is frequently evaluated [Bogaert et al., 2002]. Metrics used included Number of Patches (NP), Mean Patch Index (MPI), Edge Density (ED), Area Weighted Mean Patch Fractal Dimension (AWMPFD), Largest Patch Index (LPI), Centrality Index (CI), Compactness, and Ratio of Open Space (ROS). These eight metrics describing the spatial and temporal patterns of urban growth were computed with a view to identifying common patterns in terms of urban shape, complexity, compactness, patchiness, linearity and squareness, size of urban area and growth patterns between the civilian and military administrations [Riiters et al., 1995; Schneider et al., 2005]. Details on these metrics can be found in Bogaert et al [2002] and Huang et al [2007].

Table 1. List of Administrators and Governors in Osun State Between 1991 and 2016

\begin{tabular}{|c|c|c|c|c|}
\hline Name & Nomenclature & Inauguration & Exit & Administration \\
\hline Leo Segun Ajiborisa & Administrator & August 1991 & January 1992 & Military \\
\hline $\begin{array}{l}\text { Isiaka Adetunji } \\
\text { Adeleke }\end{array}$ & Governor & January 1992 & November 1993 & $\begin{array}{l}\text { SDP (Social } \\
\text { Democratic } \\
\text { Party) }\end{array}$ \\
\hline Anthony Udofia & Administrator & $\begin{array}{l}9 \text { December } \\
1993\end{array}$ & 22 August 1996 & Military \\
\hline Anthony Obi & Administrator & 22 August 1996 & August 1998 & Military \\
\hline $\begin{array}{l}\text { Theophilus Bam- } \\
\text { igboye }\end{array}$ & Administrator & August 1998 & May 1999 & Military \\
\hline Adebisi Akande & Governor & 29 May 1999 & 29 May2003 & $\begin{array}{l}\text { AD (Alliance for } \\
\text { Democracy) }\end{array}$ \\
\hline Olagunsoye Oyinlola & Governor & 29 May 2003 & $\begin{array}{l}26 \text { November } \\
2010\end{array}$ & $\begin{array}{l}\text { PDP (Peoples } \\
\text { Democratic } \\
\text { Party) }\end{array}$ \\
\hline Rauf Aregbesola & Governor & $\begin{array}{l}26 \text { November } \\
2010\end{array}$ & $\begin{array}{l}29 \text { November } \\
2016\end{array}$ & $\begin{array}{l}\text { APC (All } \\
\text { Progressives } \\
\text { Congress) }\end{array}$ \\
\hline
\end{tabular}


Image classification was accomplished using Environment for Visualisation software (ENVI ${ }^{\circledR}$ 5.2). The extraction of the built-up areas from other land use types and the subsequent computation of area extent of built-up area were accomplished using the ArcGIS software. The eight landscape metrics were calculated for the built-up area using FRAGSTATS [McGarigal et al., 2002]. The data used covered fourteen (14) years of military rule and sixteen (16) years of civilian administrations. Comparative analysis of the metrics between the period of military administration (19842000) and civilian administrations (2000-2014) was conducted using Paired-Sample-T-Test. In addition, Analysis of Variance (ANOVA) was used to investigate variations in built-up boundaries across different political regimes, while correlation was used to assess the relationship between urban growth and different urban growth metrics computed.

\section{Results and Disscusion}

Osogbo, the capital of Osun State, is one of the ancient towns in the south-western Nigeria (Figure 1). Osogbo became a commercial town with the arrival of railway which brought the colonial government to the town in 1907. A number of industries were also established in the town immediately after the independence in 1960. The high number of industries could be because Osogbo was made a major industrial development centre by the government of Nigeria in the 1970s. Various administrators and political parties have ruled Osun State since its creation in 1991. Military administrators oversaw the running of the state between 1991 and 1999, while civilian administrators have been in charge since 1999 till date (Table 1).

\section{Trend in Land Use Dynamics in the Osogbo Metropolis between 1984 and 2014}

In 1984, the built-up area of the Oshogbo metropolis was $54.81 \mathrm{Km} 2$ and this increased to 105.40 $\mathrm{Km} 2$ in 2014 (Table 2). This represents a 92.3\% increase at an annual growth rate of $2.2 \mathrm{~km} 2$ per annum. The metropolis increased by $12.75 \mathrm{~km} 2$ between 1984 and 1991 at an annual growth rate of $1.82 \mathrm{~km} 2$ per annum and by $14.55 \mathrm{~km} 2$ between 1991 and 2000 at an annual growth rate of $1.62 \mathrm{~km} 2$ per annum. The period $1984-$ 2000 coincide with the period of military administrators in the state. Generally, during the military era (1984 to 2000$)$, the metropolis grew by $27.30 \mathrm{~km} 2(54.0 \%)$, at an annual growth rate of $1.70 \mathrm{~km} 2$; while it grew by 23.29km2 (46.0\%) between 2000 and 2014 (civilian era), at an annual growth rate of $1.66 \mathrm{~km} 2$ per annum. This showed that the rate of growth was quite close between the two time periods. The annual rate of growth witnessed between 2003 and 2010 was quite close to what obtained between 2000 and 2003. Furthermore, between 2010 and 2014, the metropolis grew by 8.9 $\mathrm{km} 2(9.2 \%)$ at an annual rate of $2.2 \mathrm{~km} 2$. It appears that the tempo of urban expansion in the metropolis is increasing and the period between 2010 and 2013 witnessed substantial urban expansion compared to what obtained in the previous administrations.

Table 2. Urban Expansion in the Osogbo Metropolis between 1984 and 2014

\begin{tabular}{rrrr}
\hline Year & Built-up & Vegetation & Water \\
\hline 1984 & 54.81 & 93.17 & 0.03 \\
1991 & 67.56 & 76.72 & 3.72 \\
2000 & 82.11 & 62.65 & 3.25 \\
2003 & 85.30 & 59.41 & 3.30 \\
2010 & 96.51 & 48.02 & 3.48 \\
2014 & 105.40 & 39.45 & 3.15 \\
\hline
\end{tabular}

\section{Trend in Urban Growth Matrices in the Osogbo} Metropolis between 1984 and 2014

Generally, the number of urban patches decreased from 1984 through 2000 and only increased in 2003 and subsequently declined thereafter until 2014 (Table 3). The number of urban patches decreased marginally by $2.9 \%$ before 1991 . It further decreased by $6.1 \%$ between 1991 and 2000 during the military administration. Therefore, under the military rule between 1984 and 2000 , the number of urban patches decreased by $9.0 \%$. At the onset of the civilian administration between 2000 and 2003, the number of urban patches increased by $55.9 \%$ but subsequently declined by $27.6 \%$ and $25.7 \%$ between 2003 and 2010 and also between 2010 and 2014, respectively.

Generally, the Mean Patch Size (MPS) increased by $27.0 \%$ between 1984 and 1991 and by $29.37 \%$ between 1991 and 2000 . There was, however, a $49.0 \%$ reduction between 2000 and 2003. The MPS increased by $104.1 \%$ between 2003 and 2010 and by $47.0 \%$ between 2010 and 2014. Specifically, the MPS increased during the military administration between 1984 and 2000 by $64.43 \%$ but declined by $49.04 \%$ between 2000 and 2003 which coincide with the period of civilian administrator (Table 3). The mean patch size however increased by $200.22 \%$ between 2003 and 2014 under different civilian administrations. Generally, Edge Density (ED) increased between 1984 and 1991 and also in 2003, while it declined in 2000 and between 2010 and 2014 (Table 3). There was a 4.8\% increase in edge density between 1984 and 1991 which coincided with the period of military rule, while a reduction of 13.6\% was recorded between 1991 and 2000 which was also the period of military rule. There was an $18.2 \%$ increase between 2000 and 2003 which coincide with the period of civilian rule, while a reduction of $37.5 \%$ and $36.8 \%$ were recorded for the period between 2003 and 2010, and 2010 and 2014, respectively. Generally, the AWMPFD decreased in 1984 and 1991 and increased slightly in 2000 and remained constant in 2003 and 2010 but declined further to 1.3 in 2014. The highest AWMPFD was recorded at the creation of the 
Table 3. Temporal trends in urban growth metrics

\begin{tabular}{clllllllll}
\hline Years & NP & \%CNP & MPS & ED & AWMPFD & \%LPI & Centrality & Compactness & ROS \\
\hline 1984 & 102 & & 53.7 & 73.0 & 1.47 & 86.3 & 1.99 & 0.004 & 5.57 \\
1991 & 99 & -2.9 & 68.2 & 76.6 & 1.40 & 89.1 & 1.52 & 0.004 & 16.84 \\
2000 & 93 & -6.1 & 88.3 & 66.1 & 1.43 & 78.3 & 1.80 & 0.005 & 10.69 \\
2003 & 145 & +55.9 & 45.0 & 78.1 & 1.4 & 82.4 & 1.79 & 0.002 & 14.28 \\
2010 & 105 & -27.6 & 91.9 & 48.9 & 1.4 & 91.5 & 1.85 & 0.005 & 10.58 \\
2014 & 78 & -25.7 & 135.1 & 30.9 & 1.3 & 94.5 & 1.91 & 0.01 & 11.29 \\
\hline
\end{tabular}

Note NP $=$ Number of patches in the built-up area. \%CNP = Percentage change in the number of patches. MPS = Mean Patch Size. ED= Edge Density. AWMPFD = Area Weighted Mean Patch Fractal Dimension. \%LPI $=$ Percentage of the Largest Patch Index. ROS $=$ Ratio of Open Space.

Table 4. Military and Civilian Administrations

\begin{tabular}{lll}
\hline Metrics & Military & Civilian \\
\hline Built-up Area & 68.162 & 95.740 \\
Area Weighted Mean Patched & 1.404 & 1.366 \\
Fractal Density (AWMPFD) & & \\
Centrality Index (CI) & 1.767 & 1.846 \\
Compactness & 0.004 & 0.006 \\
Edge Density (ED) & 71.901 & 52.630 \\
Largest Patch Index (LPI) & 84.553 & 89.450 \\
Mean Patch Size (MPS) & 70.091 & 90.690 \\
Number of Patches (NP) & 98.000 & 109.300 \\
Ratio of Open Space (ROS) & 11.033 & 12.052 \\
\hline
\end{tabular}

state (1.42), while the lowest reduction was witnessed between 2010 and 2014, when it dropped by about 0.05 (3.7\%).

The LPI increased by 3.4\% between 1984 and 1991 but declined by $12.2 \%$ between 1991 and 2000 (military era) (Table 3 ). The LPI increased by $5.3 \%, 11.0 \%$ and 3.3\% between 2000 and 2003, 2003 and 2010, and between 2010 and 2014, respectively (civilian era). The Centrality Index (CI) decreased in 2003 but increased from 2010 onward. The CI was slightly reduced by 2003, while it increased greatly between 2010 and 2014 (civilian era). Thus, from 2010, the shape of the Osogbo metropolis assumed an elongated shape with the attendant increase in the distance between fragmented patches and the central business district (CBD) represented by the centroid of the largest urban builtup patch. The area occupied by open space increased by $11.3 \%$ between 1984 and 1991 at an annual rate of $1.4 \%$. Between 1991 and 2000, open spaces declined by $6.2 \%$ at an annual rate of $0.7 \%$. However, the area occupied by open space increased by $3.6 \%$ between 2000 and 2003 at the onset of the democratic regime, while it reduced by 3.7\% between 2003 and 2010 (civilian era). However, the metropolis experienced an increase of about $0.7 \%$ in open space availability between 2010 and 2014 .
Comparative Analysis of Urban Growth in the Osogbo Metropolis between Military and Civilian Administrations

The AWMPFD indicated that the shape of the metropolis was much complex during military administrationscompared tothecivilianadministrations. Thus, irregular urban shape characterised the metropolis during the military era between 1984 and early 2000, while the shape was gradually becoming simpler during the civilian regime from 2000 till 2014 (Table 4). Land was developed in a coordinated manner during the civilian administrations compared to what obtained during the military administrations. The centrality index also showed that the metropolis was relatively circular under the military administrations compared to civilian administrations. Urban sprawl was higher during the military administrations than during the civilian administrations, while the distance to the central business district (CBD) was fairly longer during the civilian than during the military administrations. Therefore, greater tendency toward a compact city was noticed during the civilian administrations compared to military administration.

Despite the observed variations in the metrics, the metrics were not significantly different between military 
Table 5. Correlation between Urban Growth and Landscape Metrics

\begin{tabular}{|c|c|c|c|c|c|c|c|c|c|c|}
\hline & & $\begin{array}{l}\text { Built- } \\
\text { up }\end{array}$ & $\begin{array}{l}\text { Num- } \\
\text { ber of } \\
\text { Patch }\end{array}$ & MPS & ED & $\begin{array}{l}\text { AW- } \\
\text { MPFD }\end{array}$ & LPI\% & $\begin{array}{l}\text { Cen- } \\
\text { trality }\end{array}$ & $\begin{array}{l}\text { Com- } \\
\text { pact- } \\
\text { ness }\end{array}$ & ROS \\
\hline \multirow[t]{2}{*}{$\begin{array}{l}\text { Built- } \\
\text { up }\end{array}$} & $\begin{array}{l}\text { Pearson Cor- } \\
\text { relation }\end{array}$ & 1 & & & & & & & & \\
\hline & Sig. (1-tailed) & & & & & & & & & \\
\hline \multirow{2}{*}{$\begin{array}{l}\text { Num- } \\
\text { ber of } \\
\text { Patch- } \\
\text { es }\end{array}$} & Pearson Cor- & -.161 & 1 & & & & & & & \\
\hline & Sig. (1-tailed) & .380 & & & & & & & & \\
\hline \multirow[t]{2}{*}{ MPS } & $\begin{array}{l}\text { Pearson Cor- } \\
\text { relation }\end{array}$ & $.740^{*}$ & $-.778^{\star}$ & 1 & & & & & & \\
\hline & Sig. (1-tailed) & .046 & .034 & & & & & & & \\
\hline \multirow[t]{2}{*}{$\mathrm{ED}$} & $\begin{array}{l}\text { Pearson Cor- } \\
\text { relation }\end{array}$ & $-.793^{*}$ & .629 & $-.940^{\star *}$ & 1 & & & & & \\
\hline & Sig. (1-tailed) & .030 & .091 & .003 & & & & & & \\
\hline \multirow[t]{2}{*}{$\begin{array}{l}\text { AW- } \\
\text { MPFD }\end{array}$} & $\begin{array}{l}\text { Pearson Cor- } \\
\text { relation }\end{array}$ & $-.778^{\star}$ & .414 & $-.809^{*}$ & $.912^{\star *}$ & 1 & & & & \\
\hline & Sig. (1-tailed) & .034 & .207 & .026 & .006 & & & & & \\
\hline \multirow[t]{2}{*}{ LPI\% } & $\begin{array}{l}\text { Pearson Cor- } \\
\text { relation }\end{array}$ & .385 & -.435 & .564 & -.677 & -.520 & 1 & & & \\
\hline & Sig. (1-tailed) & .225 & .194 & .122 & .070 & .145 & & & & \\
\hline \multirow[t]{2}{*}{$\begin{array}{l}\text { Cen- } \\
\text { trality }\end{array}$} & $\begin{array}{l}\text { Pearson Cor- } \\
\text { relation }\end{array}$ & .139 & -.105 & .186 & -.403 & -.578 & .060 & 1 & & \\
\hline & Sig. (1-tailed) & .396 & .421 & .362 & .214 & .115 & .455 & & & \\
\hline \multirow{2}{*}{$\begin{array}{l}\text { Com- } \\
\text { pact- } \\
\text { ness }\end{array}$} & $\begin{array}{l}\text { Pearson Cor- } \\
\text { relation }\end{array}$ & .574 & $-.815^{\star}$ & $.944^{* *}$ & $-.888^{\star \star}$ & $-.831^{\star}$ & .600 & .272 & 1 & \\
\hline & Sig. (1-tailed) & .117 & .024 & .002 & .009 & .020 & .104 & .301 & & \\
\hline \multirow[t]{2}{*}{ ROS } & $\begin{array}{l}\text { Pearson Cor- } \\
\text { relation }\end{array}$ & .212 & .264 & -.054 & .203 & .272 & .039 & $-.893^{\star *}$ & -.154 & 1 \\
\hline & Sig. (1-tailed) & .343 & .307 & .459 & .350 & .301 & .470 & .008 & .385 & \\
\hline \multicolumn{11}{|c|}{${ }^{\star}$. Correlation is significant at the 0.05 level (1-tailed). } \\
\hline \multicolumn{11}{|c|}{${ }^{* *}$. Correlation is significant at the 0.01 level (1-tailed). } \\
\hline
\end{tabular}

and civilian administrations. There was a significant difference between the built-up area during military and civilian administrations $(\mathrm{F}=7.920, \mathrm{P}<0.05)$, while other metrics were not significantly different be the military and civilian administrations.

\section{Relationship between Urban Growth and Selected Landscape Metrics}

The analysis of the relationship between urban growth and spatial metrics provides an insight into critical metrics that are influenced by the urban growth. There was a strong, positive and significant relationship between size of built-up area and MPS (0.740, $\mathrm{P}<0.05)$, while edge density $(-0.793 \quad \mathrm{P}<0.05)$ and AWMPFD $(-0.778, \mathrm{P}<0.05)$ have strong and negatively significant relationship with it. Other metrics were not significantly related to the size of the metropolis (Table 5).

One of the major arguments for administrative decentralization focuses on the need to bring governance and development closer to the grassroots levels (Cohen and Peterson, 1999; Ivanyna and Shah, 2012). Thus, administrative decentralization is an attempt at ensuring that local areas have a greater control over their own affairs and rather than being subsumed under larger political units (Miller 1981; Sokari-George 1986; Weiher, 1991; Purcell, 2001). In Nigeria, the argument for state creation has always been hinged on the need to bring governance closer to the grassroots level such that the dividend of governance is enjoyed by all (Herrera 2014). Creation of state, together with the siting of its administrative headquarters, often initiates a concomitant development, which subsequently 
leads to intensive land use/cover conversion and other associated developments that goes along with it. The creation of state initiates a new growth centre around which propulsive industries emerge. These industries provide materials that improve people's livelihood and act as agent of land conversion from agriculture or forest to urban land use.

Osogbo has been witnessing rapid urban growth since it was designated as the capital of Osun State in 1991. Its population grew from 245, 836 in 1986 to 250,951 in 1991 and to 341,120 in 2002. In 2003, its population was 350,774 , while it increased to 438,516 in 2011. The increasing population is due to the economic opportunities provided by the metropolis both as seat of government and important commercial centre. Population growth is, therefore, a major driver of urban expansion [Xiao et al., 2006; Ji et al., 2006; Surya, 2015]. The rapid population growth would ultimately translate to either horizontal or vertical growth of a city. However, such growth is often characteristically non-linear. The non-linearity could have arisen because of the various political and economic policies of government and private investors [Manson, 2001]. The interaction among government, private investors, land speculators and state of the local economy is critical in influencing the direction and intensity of city growth. Thus, urban growth politics constitute a struggle over the geography of the city in terms of the production of urban space and they involve a struggle on how best to shape urban space [Lefebvre, 1991; Gottdiener, 1994; Purcell, 2001]. The non-linearity, self-organization and co-evolution are defining characteristics of urban complexity theory [Smith and Higgins, 2003; Malanson et al., 2006].

The rate of urban expansion between 1984 and 1991 was much higher compared to what obtained between 1991 and 2000. Thus, the horizontal growth of the metropolis slowed down immediately after the creation of state and its subsequent designation as the administrative headquarters of Osun State. Rather than rapid urban sprawling of the metropolis, the process of infilling was at work. Vacant lands within the metropolis were rapidly developed for residential and commercial purposes because of the increased demand for accommodation and office space by the new migrants. The pace of urban development during the military administration was not as rapid as what was witnessed during the civilian administrations because of the prevailing Structural Adjustment Programme (SAP) embarked upon by the military administration between 1984 and 1999. SAP was one of the early neoliberal policies of the international finance institutions adopted by some developing countries, including Nigeria. The SAP emphasised expenditure reduction as well as switching of government policies from spending on social services to provision of enabling environment that will promote private investment. The reduction in government expenditures occasioned by the SAP and rampant poverty constrained investment in urban development [Ogbonna, 2012]. However, civilian administration from 1999 abandoned the SAP because of the rampant poverty and decayed infrastructure. Thus, there was injection of more funds into the provision of social infrastructure during the civilian administration than during the military administrations. Democracy affects not only social welfare, but also the strategies adopted by social and political actors to ensure equitable distribution of democratic gains [Grassi, 2014]. Revenue injection to the economy and consequently development-driven projects were made possible because of the rise in crude oil price in the world market. Therefore, differences in urban growth and its associated outcomes may be explained in terms of the political resources and incentives available to the governing elite [Goodfellow, 2013].

The number of urban built-up patches is a measure of discrete urban areas in a metropolis over time. It increases during the period of urban-nuclei development and decreases when urban areas increase and merge into continuous urban fabrics [Seto et al., 2007]. Thus, urban growth occurred during the military administration between 1984 and 2000 through a process of envelopment or annexation. This is because the larger urban built-up fabric grew and merged with smaller new and multiple urban nuclei [Seto et al., 2007]. However, at the onset of the civilian between 2000 and 2003, urban growth pattern was characterised by the process of new and multiple urban nuclei formation rather than envelopment or annexation. There was an enlargement of smaller urban-nuclei at the expense of the large built-up fabrics. Thus, the metropolis continued experiencing the process of envelopment or annexation as the largest urban built-up fabric continued to annex the new and multiple urban nuclei to become larger.

Generally, the shape of the metropolis is complex, although it is becoming gradually simple. AWMPFD usually increase during the early periods of urban growth when new urban nuclei and expansion of existing urban space creates irregularly shaped landscape patterns and will decline as urban form becomes more regular [Seto et al., 2007]. With the expansion and subsequent development of the metropolis, the degree of urban shape irregularity is declining during the civilian administrations compared to the military administrations. Urban edge density (ED) measures the total edge of urban built-up areas relative to the total urban land. An increase in edge density may result from the addition of new urban nuclei and its reduction may be due to the fusing together (annexation) of urban built-up fabric and this may lead to the dissolution of individual isolated urban patched boundaries. Thus, new urban nuclei were added between 1984 and 1991 (military era), while the reduction in edge density experienced between 1991 and 2000 (military era) could be explained in terms of annexation of smaller nuclei 
by the extant built-up fabric. Furthermore, new urban nuclei were also added between 2000 and 2003 (civilian era), as indicated by an increase in edge density, while the process of enveloping that started in 2003 continued till 2014 (civilian era). The reduction in the LPI between 1991 and 2000 (military era) may be associated with the various developmental activities embarked upon by the military administrators, which ultimately led to the reduction of the largest patch fabric. As at 2014, the largest patch accounted for as much as $94.5 \%$ of the total built-up area in the metropolis.

The compactness index (CI) measures the fragmentation of the overall urban landscape [Li and Yeh, 2004]. Generally, the built-up area is becoming increasingly compact during the civilian compared to the military administrations with less fragmentation in the urban landscape based on the results of CI. Also, the Centrality Index, which measures the average distance of the dispersed patch (fragmented patches) to the metropolis (largest patch), is also increasing. The Centrality Index also indicates whether the shape of the metropolis is elongated or circular; the more elongated the overall city shape is, the bigger the centrality index is; and vice versa [Huang et al., 2007]. Thus, the more elongated the city, the higher the distance separating the dispersed built-up patches from the CBD. The metropolis was much more elongated in 1984 compared to what it was at the creation of the state in 1991 (Table 3). In 1991, the Osogbo metropolis was relatively circular and the distance separating built-up patches from the CBD was comparatively smaller. However, by 2000, the metropolis became slightly elongated with the attendant increase in distance travelled to the CBD. The city is becoming increasingly elongated during the civilian regimes compared to what obtained during the military administrations. The porosity index measures the ratio of open space compared to the total urban area. Areas occupied by vegetation and water bodies, which appear as blank polygon in the urban landscape amount to "holes" of open space within the urban area [Li and Yeh, 2004]. There are temporal variations in the amount of open space within the Osogbo metropolis. The increasing residential development led to the large urban fabric 'consuming' the smaller ones, while all available open spaces within the metropolis were rapidly developed to meet the increasing demand for accommodation following the designation of Osogbo as administrative headquarter of the Osun State. The period between 2003 and 2010 witnessed increased urban expansion and development, leading to the development of some of the existing open spaces, most especially for recreation and commercial purposes.

The increase in the area of open space between 1984 and 1991 may have resulted from several disconnected urban patches that were in existence between these periods. High urban sprawl characterised by leapfrog and axial urban development were most predominant during this period. The reduction in open space between
1991 and 2000 (military era) could have arisen from increasing demand for land for residential development consequent upon the creation of state in 1991 during the military regime. The reduction in urban sprawl could be the result of the infilling of open spaces and vacant lands in the metropolis. The increase in the area of open space between 2010 and 2014 were mainly at the urban periphery where new developments have sprung up.

Generally, the military era tended to have relatively lower urban growth and metrics values compared to the civilian administrations [Kanianska et al., 2014]. Some of the calculated metrics were higher during the military administrations, while others were higher during the civilian administrations. Built-up area, compactness index, largest patch index, mean patch size, number of patches and ratio of open space were much higher during the civilian administrations than during the military administrations. Higher urban edge density was an indicator of the existence of many new urban nuclei during the military administrations compared to the civilian administrations. The metropolis under the civilian administrations witnessed rapid fusion (annexation) of urban built-up fabric, resulting from the dissolution of individual isolated urban patched boundaries. The results of LPI further indicated the increasing process of annexation during civilian compared to the military administrations because the LPI was higher during the civilian than during the military administration. Furthermore, the number of patches, the mean patch size and the ratio of open space were comparatively higher during the civilian administrations than during the military administrations. The higher the urban growth, the smoother the urban boundaries are owing to increasing land use conversion intensification. All other metrics did not show any significant $(\mathrm{P}>0.05)$ relationship with the size of built-up area.

Urban expansion in the Osogbo metropolis is a product of annexation and enveloping processes. These processes involve the enveloping of smaller urban nuclei by the larger patch. The union of the smaller isolated patches progressed rather slowly compared to the rate at which largest patch encroached on the smaller patch. The process of envelopment, therefore, reduces urban sprawl, as indicated by the increasing percentage of the largest patch [Li and Yeh, 2004; Seto et al., 2007; Surya, 2015]. Indeed, urban sprawl reduced during democratic administration compared to military administration. Besides, the percentage of open space is also increasing within the metropolis. The open space comprises mainly riparian vegetation along river courses and recreation playgrounds within the metropolis.

Two waves of annexation and enveloping in the metropolitan expansion can be identified. The first may have commenced prior to 1984 and continued until 2000 (the end of military regimes). The second wave of annexation and enveloping commenced in 
2000 immediately after the commencement of civilian administration and continued till 2014. These two periods were characterised by the largest urban builtup fabric encroaching into the smaller built-up nuclei. Despite this process of annexation, the few surviving urban nuclei also continue to grow and expand. The continued enlargement of these urban nuclei further predisposes them to be easily enveloped by the largest patch. Therefore, as the small urban nuclei increase, they become harnessed by the larger urban patch. This explains why the largest built-up patch accounted for about $94 \%$ of the built-up area. Despite the increasing compactness of the city, the percentage open space is increasing. The increase could have arisen as a result of the need to protect and preserve ecologically sensitive landscape within the metropolis. Such sensitive landscape includes river courses and some native forests. Apart from the ecologically sensitive areas, the rising interest in sporting and recreational activities has led to the opening of many neighbourhood recreational facilities in the metropolis.

\section{Conclusion}

The use of remote sensing and landscape metrics provide opportunity to quantitatively investigate the urban expansion process and estimate the impact of such expansion. The use of remotely sensed data provides opportunity to compare urban growth over time, and growth across different political dispensations. It thus provides basis for evaluating the contribution of different political administrations to urban growth. The metrics used provided the basis for accessing the contributions of each administration type to urban development in terms of sprawl minimization, minimization of distance to the central business district, and understanding of the dominant urbanization process that characterised each administration. Despite the significant difference in urban growth during the military and civilian administrations, the effects of urban growth on distance to central business district, available open space, urban sprawl, and shape of builtup areas, are not significantly different between the military and civilian administrations. In addition, urban expansion occurred primarily through expansion of extant urban areas rather than spontaneous and detached development [Seto et al., 2007]. It is, therefore, imperative for civilian administrators to fashion policies that will ensure that, beyond the policies aimed at urban growth, there are programmes and policies that will ensure that the citizenry enjoy the benefits associated with such growth.

\section{References}

Bogaert, J., Zhou, L., Tucker, C. J., Myneni, R. B., and Ceulemans, R. (2002). Evidence for a persistent and extensive greening trend in Eurasia inferred from satellite vegetation index data. Journal of Geophysical Research: Atmospheres, 107(D11).
Cohen, J. M., Peterson, S. B., \& Peterson, S. B. (1999). Administrative decentralization: Strategies for developing countries (pp. 94-96). West Hartford, CT: Kumarian Press.

Goodfellow, T. (2013). Planning and development regulation amid rapid urban growth: explaining divergent trajectories in Africa. Geoforum, 48, 8393.

Gottdiener, M. (1994). The social production of urban space. University of Texas Press.

Grassi, D. (2014). Democracy and Social Welfare in Uruguay and Paraguay. Latin American Politics and Society, 56(1), 120-143.

Gupta R.P., and Prakash, A. (1998). Land-use mapping and change detection in a coal mining area- a case study in the Jharia coalfield, India. International Journal of Remote Sensing 19(3), 391-410.

Herrera, V. (2014). Does commercialization undermine the benefits of decentralization for local services provision? Evidence from Mexico's urban water and sanitation sector. World Development, 56, 1631.

Huang, J., Lu, X. X., and Sellers, J. M. (2007). A global comparative analysis of urban form: Applying spatial metrics and remote sensing. Landscape and Urban Planning, 82(4), 184-197.

Ivanyna, M., and Shah, A. (2012). How close is your government to its people? Worldwide indicators on localization and decentralization. Worldwide Indicators on Localization and Decentralization (July 1, 2012). World Bank Policy Research Working Paper, (6138).

Ji, W., Ma, J., Twibell, R. W., and Underhill, K. (2006). Characterizing urban sprawl using multi-stage remote sensing images and landscape metrics. Computers, Environment and Urban Systems, 30(6), 861-879.

Kanianska, R., Kizeková, M., Nováček, J., and Zeman, M. (2014). Land-use and land-cover changes in rural areas during different political systems: a case study of Slovakia from 1782 to 2006. Land Use Policy, 36, 554-566.

Lefebvre, H. (1991). The production of space (Vol. 142). Blackwell: Oxford.

Li, X., and Yeh, A.G.O. (2004). Analyzing spatial restructuring of land use patterns in a fast growing region using remote sensing and GIS. Landscape and Urban Planning. 69(4), 335-354.

Logan, J., and Molotch, H. (1987). Urban fortunes: The Political Economy of Place. Berkeley, University of California Press.

Malanson, G. P., Zeng, Y., and Walsh S. J. (2006). Complexity at advancing ecotones and frontiers. Environment and Planning A, 38(4), 619-632.

Manson, S. M. (2001). Simplifying complexity: a review of complexity theory. Geoforum, 32(3), 405-414.

McGarigal, K., Cushman, S. A., Neel, M. C., and Ene, E. (2002). FRAGSTATS: spatial pattern analysis 
programme for categorical maps. Available at: http://www.umass.edu/landeco/research/fragstats/ fragstats.html.

Miller, G. J. (1981). Cities by contract: The politics of municipal incorporation. MIT Press.

Molotch H. (1993). The political economy of growth machines. Journal of Urban Affairs 15 (1), 29-53.

Ogbonna B. C. (2012). Structural Adjustment Programme (SAP) in Nigeria: An Empirical Assessment. Journal of Banking, 6 (1), 19 - 40. Available http://www.academia.edu/3627738/ Structural_Adjustment_Program_SAP_in_ Nigeria_An_Empirical_Assessment. Accessed 29th January 2014.

Polanyi K. (1944). The great transformation. New York: Rinehart, 209-227.

Purcell, M. (2001). Metropolitan political reorganization as a politics of urban growth: the case of San Fernando Valley secession. Political Geography 20(5), 613-633.

Ramachandra T. V., Aithal, B. H., and Sanna D.D. (2012). Insights to urban dynamics through landscape spatial pattern analysis. International Journal of Applied Earth Observation and Geoinformation, 18, 329-343.

Riiters, K. H., O’neill, R. V., Hunsaker, C. T., Wickham, J. D., Yankee, D. H., Timmins, S. P., Jones, K. B., and Jackson, B. L. (1995). A factor analysis of landscape pattern and structure metrics. Landscape Ecology 10(1), 23-39.

Schneider, A. (2012). Monitoring land cover change in urban and peri-urban areas using dense time stacks of Landsat satellite data and a data mining approach. Remote Sensing of Environment, 124, 689-704.

Schneider, A., Seto, K. C., and Webster, D. R. (2005). Urban growth in Chengdu, Western China: application of remote sensing to assess planning and policy outcomes. Environment and Planning B: Planning and Design, 32(3), 323-345.

Seto, K. C., Fragkias, M., and Schneider, A. (2007). 20 years after reforms: Challenges to planning and development in China's city-regions and opportunities for remote sensing. In Applied Remote Sensing for Urban Planning, Governance and Sustainability (pp.249-269). Springer Berlin Heidelberg.

Shu, B., Zhang, H., Li, Y., Qu, Y., and Chen, L. (2014). Spatiotemporal variation analysis of driving forces of urban land spatial expansion using logistic regression: A case study of port towns in Taicang City, China. Habitat International, 43, 181-190.

Sirowy, L., and Inkeles, A. (1990). The effects of democracy on economic growth and inequality: A review. Studies in Comparative International Development, 25(1), 126-157.

Smith, W., and Higgins, M. (2003). Postmodernism and popularisation: The cultural life of chaos theory. Culture and Organization, 9(2), 93-104.

Sokari-George E (1986) New towns as growth centres; A case study in Nigeria. Indonesian Journal of Geography. 16(52) 9-20

Solé-Ollé, A., and Viladecans-Marsal, E. (2013). Do political parties matter for local land use policies? Journal of Urban Economics, 78, 42-56.

Surya B. (2015) The dynamics of spatial structure and spatial pattern changes at the fringe area of Makassar City. Indonesian Journal of Geography, 47(1) 11-19.

Thapa, R. B., and Murayama, Y. (2010). Drivers of urban growth in the Kathmandu valley, Nepal: Examining the efficacy of the analytic hierarchy process. Applied Geography, 30(1), 70-83.

Wangome J. (1985). Military coups in Africa: The African neo-colonialism that is self-inflicted. Retrieved at: http://www.globalsecurity.org/ military/library/report/1985/WJ.htm (accessed 30.01.2016).

Weiher, G. (1991). The fractured metropolis: Political fragmentation and metropolitan segregation. State University of New York Press.

Xiao, J., Shen, Y., Ge, J., Tateishi, R., Tang, C., Liang, Y., and Huang, Z. (2006). Evaluating urban expansion and land use change in Shijiazhuang, China, by using GIS and remote sensing. Landscape and urban planning, 75(1), 69-80.

Yu, X. J., and Ng, C. N. (2007). Spatial and temporal dynamics of urban sprawl along two urban-rural transects: A case study of Guangzhou, China. Landscape and Urban Planning, 79(1), 96-109.

Zhang, Q., Wallace, J., Deng, X., and Seto, K. C. (2014). Central versus local states: Which matters more in affecting China's urban growth? Land Use Policy, 38, 487-496.

Zhang, Z., Su, S., Xiao, R., Jiang, D., and Wu, J. (2013). Identifying determinants of urban growth from a multi-scale perspective: A case study of the urban agglomeration around Hangzhou Bay, China. Applied Geography, 45, 193-202. 